\title{
THE FARTHEST MOSQUE OR THE ALLEGED TEMPLE AN ANALYTIC STUDY
}

\author{
Yehia Hassan Wazeri
}

\author{
Assistant professor - Dept. of Architecture \\ High Institute of Engineering \& Technology, \\ Al Arish, Egypt. \\ Email: drwazeri@yahoo.com
}

\begin{abstract}
The Farthest Mosque (Al-Masjid Al-Aqsa in Jerusalem) has been associated in the consciousness of the Muslims, with The Sacred Mosque (Al-Masjid Al-Haram in Makkah) through a spiritual bond since the event of Isra' (Night Journey) and $\mathrm{Mi}$ 'raj (Ascension to Heaven). The objective of this study is to determine the orientation of the Farthest Mosque and illustrate the similarity in geometric shape (plan) and proportions, between the Farthest Mosque in Jerusalem and the sacred mosque (Al-Ka 'bah) in Makkah, in the first part of the research. The second part of the research involves a study of some texts from the Old Testament that address the architectural and structural descriptions of the alleged temple, with the purpose of exposing whether glaring contradictions exist between the texts of the Old Testament themselves or between them and the real architectural and structural facts acknowledged by specialists in this field.
\end{abstract}

Keywords: The Farthest mosque, the Alleged Temple, Al-Ka 'bah, geometric similarity

\begin{abstract}
Abstrak
Masjid tertua (Masjid al-Aqsa di Jarusalem) telah dihubungkan dalam kesadaran umat muslim, dengan masjid suci (Masjidil Haram di Mekah) melalui ikatan spiritual sejak kejadian Isra' (perjalanan malam) dan Mi'raj (kenaikan ke surga). Tujuan dari kajian ini adalah untuk menentukan orientasi masjid tertua and menggambarkan kesamaan bentuk geometri (denah) dan proporsi, antara masjid tertua di Jarusalem dan masjid suci (Ka'bah) di Mekah, di bagian pertama penelitian. Bagian kedua penelitian melibatkan kajian beberapa tulisan dari surat wasiat kuno yang mengarah kepada deskripsi arsitektural dan struktural kuil, dengan tujuan mengekspos baik kontradiksi yang mencolok antara tulisan surat wasiat kuno itu sendiri maupun di antara mereka, dan fakta arsitektural dan struktural yang nyata diakui oleh spesialis di lapangan
\end{abstract}

Kata kunci: masjid tertua, kuil, ka’bah, kesamaan geometri

\section{Introduction}

The Farthest Mosque (Al-Masjid Al-Aqsa in Jerusalem) has been associated in the consciousness of the Muslims, with The Sacred Mosque (Al-Masjid Al-Haram in Makkah) through a spiritual bond since the event of Isra' (Night Journey) and Mi'raj (Ascension to Heaven). Moreover, Allah (Exalted be $\mathrm{He}$ ) assigned a special chapter (Sura) in the Glorious Qur'an bearing the title "Al-Isra"' in commemoration of that blessed event.

Indeed, the importance of addressing the issue of Al-Masjid Al-Aqsa springs from several perspectives, on top of which is the fact that it is the first Qiblah (direction faced in Prayer) to which the Muslims directed their faces during prayer, and that it is the third Masjid next to the Two Sacred Mosques (AlHaramayn Ash-Sharifayn: Al-Masjid Al-Haram in Makkah and the Prophet's Mosque in Madinah), to which the Muslims are allowed to undertake journeys with the sole purpose of worship. The importance increases at the present time, especially due to the incessant attacks and encroachments committed by the Israeli occupation that has befallen this Masjid. For, the Jews falsely and unjustly assert a historical right to the city of Jerusalem and its blessed mosque. From time to time, they openly declare their intention and determination to reconstruct their alleged temple over the debris of Jerusalem Shrine (Al-Haram Al-Qudsi) and that they are waiting for the optimum circumstances during which they can achieve their plan.

The approach adopted in this study utilizes architectural and archeological milestones as material evidence that can be relied on, in proving the Islamic identity of the Farthest mosque (AlMasjid Al-Aqsa). That is illustrated in the first part of 
the present study through proving that the Qiblah of Al-Masjid Al-Aqsa was diverted to Makkah AlMukarramah hundreds of years before the Muslim conquest of Jerusalem. It is also indicated through proving the architectural symmetry and identical nature that exists between Al-Masjid Al-Aqsa and The Sacred Mosque in Makkah (Al-Ka 'bah).

The second part of the research involves a study of some texts from the Old Testament that address the architectural and structural descriptions of the alleged temple, with the purpose of exposing whether glaring contradictions exist between the texts of the Old Testament themselves or between them and the real architectural and structural facts acknowledged by specialists in this field. This confirms that the existence of the temple, as is alleged by the Jews, is a baseless and fabricated notion; as over more than a hundred and fifty years of archeological excavations in Jerusalem and around and underneath Al-Masjid Al-Aqsa prove that it is baseless.

\section{Aspects of Similarity Between Al-Masjid Al- Aqsa and Al-Ka 'bah}

1. The Concept and Limits of Al-Masjid Al-Aqsa

Al-Masjid Al-Aqsa is located in Jerusalem, and it has been the sacred capital and most important city in Palestine for time immemorial. It is also one of the most important capitals and cities in the Islamic world. Here, it is worth noting that the Old City is that which lies within the fence that was established and renewed by Sulayman Al-Qanuni, and it is surrounded by valleys and hills on all sides. This sacred city is situated in $31.52^{\circ} \mathrm{N}$. latitude and 35.13 E. longitude. It was established upon four spurs: Mount Moriah upon which Al-Masjid Al-Aqsa (AlHaram Al-Qudsi) is built southeast of the city, Mount Zion - which is known as King David's Mount, and it constitutes the south-eastern part of the four mounts of Jerusalem, Mount Accra wherein lies the Church of the Resurrection, and the Mount of Olives which is located near Bab Al-Sahirah (Herod's Gate) ${ }^{1}$.

Al-Masjid Al-Aqsa and its external yards that are walled with the stone fence on the southern side is located east of the Old City, and it is established upon Mount Moriah, occupying an area of approximately 150 acres (one acre equals $1000 \mathrm{~m}^{2}$ ). It is encompassed by a stone wall, the western side of which is $490 \mathrm{~m}$, the eastern $474 \mathrm{~m}$, the northern 321 $\mathrm{m}$, and the southern $283 \mathrm{~m}$, figure 1 .

Many people think that Al-Masjid Al-Aqsa is only the mosque established south of the Dome of the Rock, where the obligatory five daily prayers are performed now. Actually, Al-Masjid Al-Aqsa is a term that applies to all parts of the Masjid, including the area encompassed within the wall, such as the gates, the spacious yards, the mosque itself, the Dome of the Rock, Al-Musalla Al-Marawani, the corridors, domes, terraces, free drinking water (springs), and other landmarks, like minarets on the walls. Furthermore, the whole mosque is unroofed with the exception of the building of the Dome of the Rock and Al-Musalla Al-Jami ", which is known by the public as Al-Masjid Al-Aqsa. The remaining area, however, is a yard of the mosque. This is agreed upon by scholars and historians, and accordingly, the doubled reward for performing prayer therein is attained if the prayer is performed in any part of the area encompassed by the wall ${ }^{2}$.

Indeed, Al-Masjid Al-Aqsa, which is mentioned in Almighty Allah's Glorious Book in the first verse of Sura Al-Isra' is the blessed place that is now called the Noble Sanctuary (Al-Haram Al-Qudsi Ash-Sharif) which is enclosed within the great fence and what is built over it. Moreover, what applies to the mosque applies by corollary to the wall encircling it, since it is part of it. Such is the legal definition of Al-Masjid Al-Aqsa ${ }^{3}$.

Regarding the concept (definition) of Al-Masjid Al-Aqsa, Shaykh 'Abdul-Hamid Al-Sa'ih, former Minister of (Religious) Endowments and Islamic Sanctuaries in Jordan said ${ }^{4}$ : "The term Al-Masjid AlAqsa, for the Muslim public, denotes all that is encircled by the wall of Al-Masjid Al-Aqsa, including the gates".

Therefore, (the legally defined) Al-Masjid Al-Aqsa and Al-Haram Al-Qudsi Ash-Sharif (the Noble Sanctuary) are two names for the same place, knowing that Al-Haram Ash-Sharif is a name that has only been coined recently.

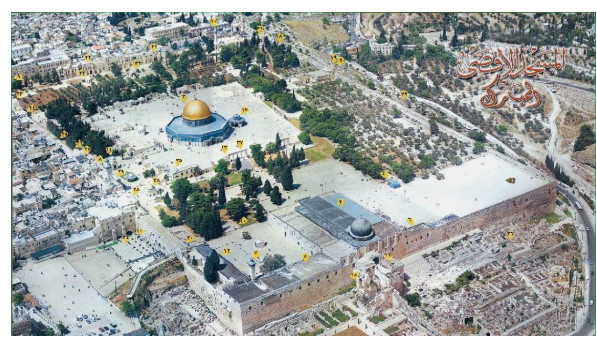

Figure 1a. Overview of Al-Masjid Al-Aqsa.



Figure. 1b. Dimensions of the Walls of Al-Masjid Al-Aqsa that Delimits Al-Haram Ash-Sharif (drawn by the researcher) 
2. Determine the Orientation of Al-Masjid AlAqsa (Al-Haram Al-Qudsi)

Geographic orientation is one of the most important characteristics of a building that determines the identity of any building, especially if it has a religious function. As it is already known, one of the main determinants, regarding design of the mosque, is that the Qiblah wall is oriented towards Makkah Al-Mukarramah, i.e. in the direction of Al-Masjid Al-Haram at Makkah Al-Mukarramah.

Moreover, a Prophetic hadith indicates that AlMasjid Al-Aqsa is the second Masjid ever established for mankind on earth, next to Al-Masjid Al-Haram, for, it is reported in the two Sahih (authentic books of hadith of Al-Bukhari and Muslim) from Abu Dhar Al-Ghifari (may Allah be pleased with him) that he said, "I asked, 'O Messenger of Allah! Which Masjid was first established on earth?' He answered, 'AlMasjid Al-Haram'. I then asked, 'Which was next?' He said, 'Al-Masjid Al-Aqsa'. I further asked, 'How much time was there between [the building of] the two?' He replied, 'Forty years' Then, he said, 'Wherever you may be, at the time of prayer, you may pray for it [the earth] is all a mosque; for excellence lies (in performing prayer) therein".

This hadith clearly affirms that Al-Masjid Al-Aqsa was established on earth after Al-Masjid Al-Haram, which means that the Qiblah of Al-Masjid Al-Aqsa must have been oriented towards Makkah AlMukarramah, where Al-Masjid Al-Haram, a long time before the coming of the Selected Prophet (Muhammad, peace be upon him $)^{5}$.

In order to prove the validity of this hypothesis, the researcher utilized "Oibla Locator (software) program"6, in which real satellite pictures are employed in identifying the direction to which the southern wall of Al-Haram Ash-Sharif containing the Qiblah to the southern (covered) mosque is oriented, figure 2 .

The direction of the Qiblah in Jerusalem is 156.21 degree, being measured clockwise from the real north. The aerial picture illustrates that the main axis of the southern covered mosque (and likewise of Al-Haram Al-Qudsi in general) is diverted about 11.81 degree from the virtual direction of the Qiblah, figure 3.

Furthermore, if the circumference of planet earth is exactly equal to 360 degrees, this means that the ratio of diversion of the Qiblah of Al-Masjid Al-Aqsa from the side of Makkah Al-Mukarramah is about $3 \%$, knowing that this is a slight ratio that can be overlooked. Hence, it means that the main axis of the area of the Al-Masjid Al-Aqsa (Al-Haram AshSharif) is oriented towards Makkah Al-Mukarramah, the Qiblah of the Muslims all over the world.

Indeed, this proof is considered a substantial material indication that cannot be ignored and it proves that this spot, the neighborhood of which has been blessed by Allah (Exalted be He), is oriented towards Makkah Al-Mukarramah, wherein lies the honorable Ka 'bah (the Qiblah), the first house of worship ever established for mankind on earth.



Figure 2. A Virtual Aerial Picture of Al-Masjid Al-Aqsa (AlHaram Al-Qudsi), which Indicates the Direction of Makkah Al-Mukarramah in Red Line, Using Qibla Locator Program (A Study Conducted by the Author)



Figure 3. The Main Axis of Al-Haram Al-Qudsi is Almost Oriented Towards Makkah Al-Mukarramah with a Slight Diversion (Studied and Drawn by the Researcher).

The foundations of the walls of the current AlMasjid Al-Aqsa (Al-Haram Al-Qudsi) has been there since the reign of Herod the Great (died in 4 B.C.) in Jerusalem. This was discovered through the excavations carried out by Charles Warren in 1867 A.C., reaching a depth of $24 \mathrm{~m}$. below the surface of the earth ${ }^{7}$, figure. 4. This was done under the auspices of the authority financing excavations for the monuments of Palestine that was established in 1865 A.C ${ }^{8}$. 


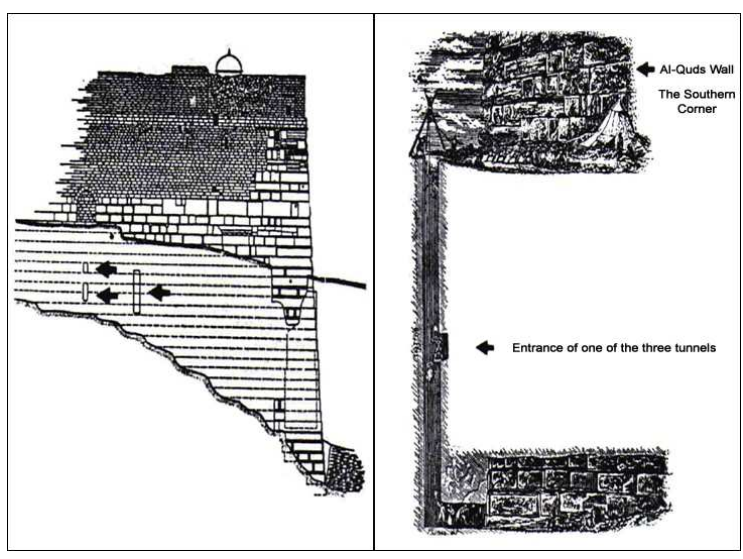

Figure 4a. A Vertical Section in One of the Charles Warren Tunnels and the Locations of Such Tunnels on the Wall of Al-Masjid Al-Aqsa, which Indicate One of the Sides of the Original Foundations of Al-Masjid Al-Aqsa, which Date Back to the Reign of (Herod the Great).

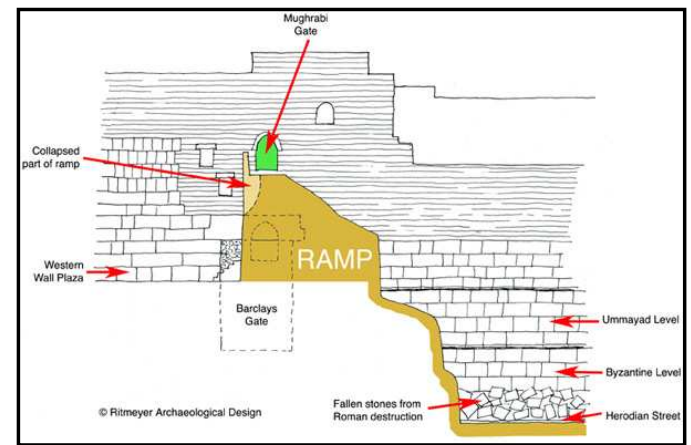

Figure 4b. A Section and an Elevation Towards the Side of Al-Maghariba Gate and the Western the Lower Stratum of the Western Wall of Al-Masjid Al-Aqsa Since the Reign of (Herod the Great) [The Drawing is Quoted from the Website of the Jewish Archeologist, Leen Reitmeyer ${ }^{9}$ ].

Thus, it means that the current main longitudinal axis of Al-Masjid Al-Aqsa was oriented towards the Qiblah about 640 A.C. before the Muslim conquest of Jerusalem in 15 A.H/638 A.C. This gives a clear indication that the area of Al-Masjid Al-Aqsa was oriented towards the Qiblah a long time ago. This is also mentioned without being corroborated by evidence in a recent scientific research ${ }^{10}$.

\section{A Study of Geometric Shape and Proportions of Al-Masjid Al-Aqsa}

\section{A Study of the Geometric Shape}

The measurements of the walls of which represent the limits of Al-Masjid Al-Aqsa (refer back to figure.1b) - are as follows ${ }^{11}$ :

- The eastern side: $474 \mathrm{~m}$.

- The northern side: $321 \mathrm{~m}$.

- The western side: $490 \mathrm{~m}$.
- The southern side: $283 \mathrm{~m}$.

Through studying the preceding dimensions, it becomes clear that none of the identified sides of Al-Masjid Al-Aqsa is equal to the other, just as none of these sides is parallel to the other. Any geometric shape that has these descriptions is called "trapezium" or "trapezoid"12, knowing that such is among the geometric shapes that are rarely used in designing the horizontal projections of buildings or determining the walls of sites.

\section{A Study of the Geometric Proportions}

The researcher investigated the geometric proportions of Al-Masjid Al-Aqsa according to the dimensions referred to above, and reached the following findings:

- The average relation of the length of AlHaram Al-Qudsi to its width is $1: 1.59$, figure 5 .

- The real relation of the southern side of AlHaram Al-Qudsi to the eastern side is 1:167, figure $5 b$.

This means that the geometric proportions of AlMasjid Al-Aqsa is almost symmetrical to the "golden ratio" which equals $1: 1618^{13}$. It was thus called because it is the proportion most comforting to the eye from visual and aesthetic perspectives. That is why it is said that the golden rectangle (rectangular figure) is the most pleasurable sight to the beholder ${ }^{14}$.
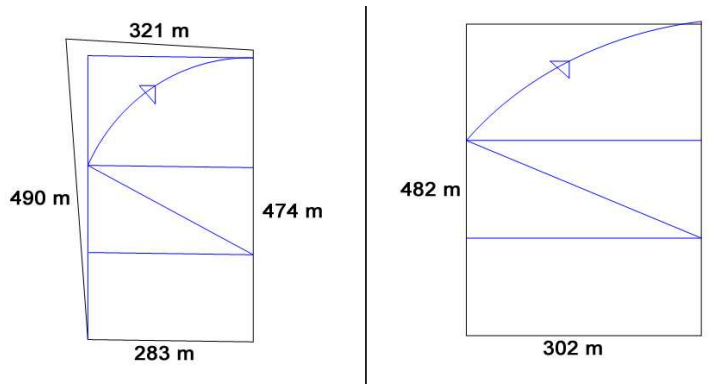

Figure 5a. Average Proportion Figure 5b. Real Proportion

Figure 5. The Geometric Proportions of Al-Masjid Al-Aqsa are Almost in Line with the "Golden Ratio [Golden Section]" (Studied and Drawn by the Researcher).

Aspects of Geometric Similarity Between AlMasjid Al-Aqsa and the Honorable Ka 'bah

Since I conducted a study on the shape and geometric proportions of the Al-Masjid Al-Aqsa, I - in like manner - have conducted a study of the geometric characteristics of the Honorable Ka ${ }^{\text {bah }}{ }^{15}$, whose foundations were laid by Prophet Ibrahim 
(Abraham) and his son, Isma il (Ishmael), knowing that this fact is stated in the Glorious Qur'an.

In this regard, the famous English archeologist, $\mathrm{K}$. Creswell, stated in his famous book Early Muslim Architecture $^{16}$, that the original dimensions of the Ka 'bah - according to the report of Al-Azraqi ,figure. 6 - are as follows ${ }^{17}$ :

- The northern-east side: 32 cubits.

- The north-west side: 22 cubits.

- The south-west side: 31 cubits.

- The south-east side: 20 cubits.

This means that none of the original sides of the Ka 'bah equals any of its other sides, and that no side parallels any other one. Such are the features of the quadrilaterals that are geometrically called "trapeziums", and this means that the geometric description of the shape of the horizontal projection of the Honorable Ka 'bah corresponds exactly with the geometric description of the shape of Al-Masjid Al-Aqsa, knowing that this is the first aspect of geometric parallelism between them.

Here, it is worth noting that the original measurements of the Ka 'bah - as stated in AlAzraqi's book (News of Makkah) - just as they were established by Prophet Ibrahim - differ from the

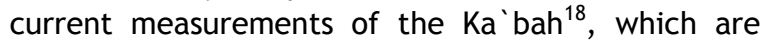
several cubits smaller from the side of Isma 'il's Hijr (short semi-circular wall adjacent to the Ka 'bah and considered part of it) since Quraysh rebuilt it ${ }^{19}$.

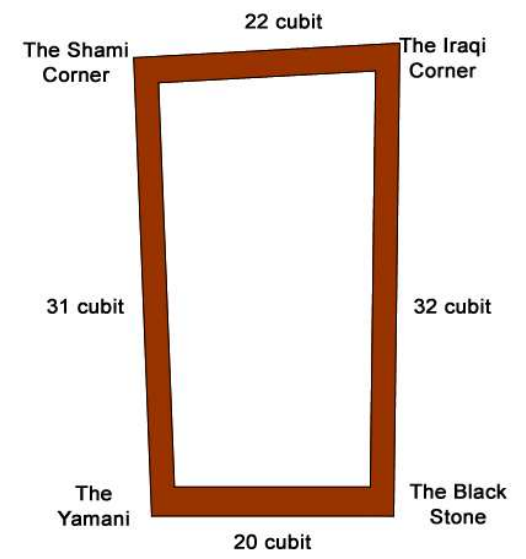

Figure 6. A Plan of the Honorable Ka 'bah Just as They were Laid by Prophet Ibrahim (drawn by the researcher).

According to the geometric analysis of the original measurements of the Honorable Ka bah plan, as it was established by Prophet Ibrahim (peace be upon him), the following conclusion has been reached:

- The average ratio of the width of the building of the Ka 'bah to length is $1: 1.50$.

- The real ratio of the wall of the Ka 'bah, between the Black Stone Corner and the
Yemeni Corner, to the wall of the Ka'bah, between the Black Stone Corner and the Iraqi Corner, is $1: 1.60$, which corresponds exactly with the golden ratio, See figure 7 .

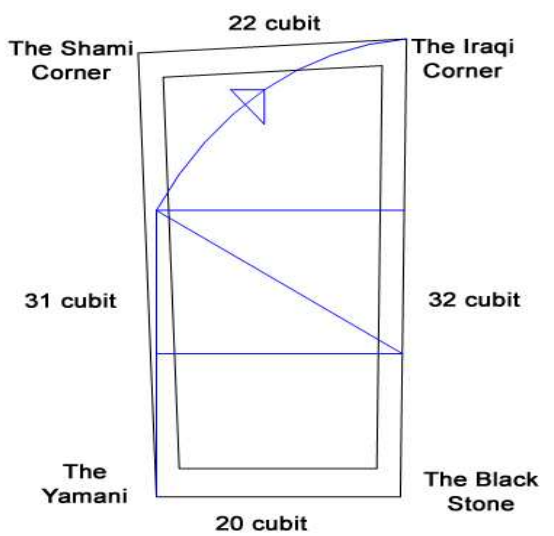

Figure 7. The Real Geometric Ratios of the Ka 'bah Dimensions Match the Golden Ratio (Studied and Drawn by the Researcher).

The preceding conclusions indicate the extent of similarity, and rather geometric identicalness, between Al-Masjid Al-Aqsa and the Honorable Ka 'bah, as was laid by Prophet Ibrahim and his son Isma il, which is clearly illustrated through the comparison drawn in table 1. This table indicates that the geometric shape of both Al-Masjid Al-Aqsa and the Honorable Ka 'bah is a trapezium, which is one of the rarely used shapes in the structural design of buildings. This is because no side of this shape equals or parallels another. Besides, the geometric ratios of both mosques (Masjids) are almost identical, and they both equal the "golden ratio", which is considered to be the best geometric ratio ever.

Table 1. Geometric Similarity and Correspondence Between Al-Masjid Al-Aqsa (Al-Haram Al-Qudsi) and the Honorable Ka 'bah in Its Original Dimensions (the Researcher)

\begin{tabular}{|c|c|c|}
\hline $\begin{array}{c}\text { Aspects of } \\
\text { geometric } \\
\text { similarity and } \\
\text { correspondence }\end{array}$ & $\begin{array}{c}\text { Al-Masjid Al- } \\
\text { Aqsa (Al- } \\
\text { Haram Al-Qudsi) }\end{array}$ & $\begin{array}{c}\text { The Honorable } \\
\text { Ka 'bah (original } \\
\text { dimensions) }\end{array}$ \\
\hline $\begin{array}{c}\text { Geometric } \\
\text { shape }\end{array}$ & $\begin{array}{c}\text { Trapezium } \\
\text { (rarely used } \\
\text { shape) }\end{array}$ & $\begin{array}{c}\text { Trapezium (rarely } \\
\text { used shape) }\end{array}$ \\
\hline $\begin{array}{c}\text { Average } \\
\text { geometric ratio }\end{array}$ & $1: 1.59$ & $1: 1.50$ \\
\hline $\begin{array}{c}\text { Real geometric } \\
\text { ratio }\end{array}$ & $\begin{array}{c}1: 1.67 \text { (Almost } \\
\text { the golden ratio) }\end{array}$ & $\begin{array}{c}1: 1.60 \text { (Almost } \\
\text { the golden ratio) }\end{array}$ \\
\hline
\end{tabular}

Can this parallel in geometric shape or ratios be considered a coincidence ${ }^{20}$. Or does this geometric matching indicate the extent of material bonding 
between Al-Masjid Al-Aqsa and the Honorable Ka 'bah, knowing that this bond is maintained in the Glorious Qur'an and the Noble Sunnah! Indeed, this undeniably confirms the Islamic identity of the Blessed Al-Aqsa Masjid, especially that its Qiblah faces towards Makkah Al-Mukarramah, knowing that this has been the case even several centuries before the Islamic conquest of the Sacred Bayt Al-Maqdis (Jerusalem), as is indicated above.

\section{Contradictions in the Description of the Alleged Temple in the Old Testament}

\section{The Adopted Approach}

The Jews depend, in their allegation that king Solomon $^{21}$ had built a temple for worship in the current site of Al-Masjid Al-Aqsa, on the Old Testament texts, with the aim of lending a religious tenor and sanctity to their claim. This claim, however, was refuted through all excavations in Jerusalem and under and around Al-Masjid Al-Aqsa for over more than a hundred and fifty years ${ }^{22}$.

On the other hand, we - the Muslims - firmly believe that this alleged temple is no more than a lie and that it has never existed, since none of the religious texts of the Qur'an and authentic prophetic Hadiths mentioned that Prophet Solomon built a temple. Rather, he renewed the building of AlMasjid Al-Aqsa ${ }^{23}$.

We will now highlight the scientific approach, which we follow in the present part as follows:

1. The text of the Old Testament that addresses the alleged temple, in the translated Arabic version and also the English version are studied in order to fully ascertain the identical nature between the translated Arabic text of the Old Testament and its English counterpart, as regards architectural description and geometric measures.

In this regard, we have referred to more than one English version, due to the multiplicity of versions that exist. This is because we noticed the existence of adaptations to some of the measurements of the temple (particularly the height of the temple's porch) in some modern versions. This becomes quite clear upon comparing it to the relatively old English versions, which completely agree with the translated Arabic version of the Old Testament.

2. There is no reference to the Jewish creed or the contradictions in the Old Testament in general, since it is not relevant to the field of this research ${ }^{24}$. However, the focus is on texts that describe the alleged temple from the architectural and geometric perspective to prove the contradictions introduced therein.

3. Drawings and models of the alleged temple and pictures of it have been quoted through several
Israeli electronic websites for the study and description of the temple according to what is mentioned in the Old Testament, to prove the manifest contradiction in the texts of the Old Testament which is in turn reflected in these drawings and three-dimensional models.

2. Description of the alleged temple as mentioned in the Old Testament:

"The temple" is a word which in Hebrew is equivalent to "Beit HaMikdash", that is "House of the Holy" or Hekhal, which means the "Big House" in many Semitic languages (the Acadian, the Canaanite, and so on.). The Big or Great House is a term used in reference to the house of God, while the word "Pharaoh" meant "the Big House", which is somewhat similar to the phrase "The High Gate". Besides, the Jewish Immanentism class that had accumulated within the Jewish geological structure, surfaced in the form of reverence for the earth, represented in the worship of Yisrael and central sacrificial worship that is linked to the united Hebrew states (1020 B.C.), the rituals of which were supervised by the priests, knowing that the center of this ritual worship was the temple. Among the other most important names of the temple is the "House of Yahweh", since it is originally the house of the God and not a place of worship (unlike the Ka'bah). Hence, none of the priests or even the slaves of the temple were allowed to freely move around in the temple, even though they were allowed to enter it. Moreover, no one was allowed to enter the Holy of Holies except the High Priest on Yom Kippur"25.

A detailed description of the alleged Solomon's temple, as regards the time of building it, its measurements, the materials used in building it and the total area, was mentioned in some books of the Old Testament, which are read as follows:

- Kings 1: Chapter 5 to Chapter 8.

- Kings 2: Chapter 25.

- Chronicles 2: Chapter 2 to Chapter 4.

- Ezekiel: Chapter 40 to Chapter 42.

The rebuilding of the (second) temple was also mentioned in Ezra, chapters 3 and 6, after the return from Babylonian captivity, yet without mentioning the detailed descriptions of that building as is mentioned about the description of the (first) temple, which had been built by King Solomon, according to their own belief. An exception to this is a single reference to the measurements of the foundations of that (second) temple and a description of a number of rows of stone used in it.

According to what is mentioned above and depending on the description in the Old Testament, the alleged Solomon's temple is made up of the following basic elements ${ }^{26}$, figures $8 \mathrm{a} \& 8 \mathrm{~b}$. 
1. The entrance porch $C$, with two pillars in front of it (Boaz and Jachin, $\mathrm{H}$ ).

2. The Court of Priests (D), which contains seven-branches candlesticks $(F)$, tables for showbread $(E)$ and the altar of incense $(C)$.

3. The Holy of Holies (A), which contains the Ark of the Covenant.

4. Chambers surrounding the building from three sides (north, south and west), (L).

5. The Bronze Sea in front of the building (I).

6. The Altar of burnt-offering, in front of the building $(\mathrm{J})$.

7. Several buildings and open yards, according to what is mentioned in Ezekiel.

8. A square wall surrounding all that is mentioned above, according to what is stated in Ezekiel.

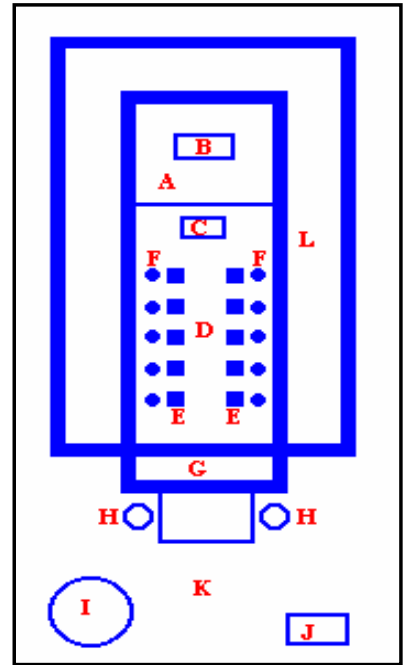

Figure 8a. Plan Indicates the Basic Components of the Alleged Temple as Described in the Old Testament.

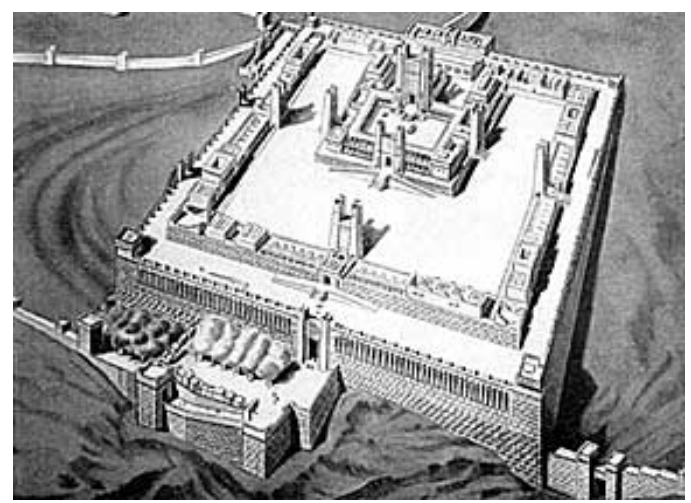

Figure 8b. Imagined Perspective that Illustrates the Alleged Temple and the Surrounding Buildings and Yards, and Finally the Square Wall that Encompasses it According to the Description Mentioned in Ezekiel Chapter.
Contradictions in the Description of the Old Testament Regarding the Alleged Temple

1. Contradiction Regarding the Numbers of Officials Supervising Laborers

Some texts from the Old Testament mentioned the numbers of laborers that Solomon employed in cutting stones for the temple. It mentions that they cut stones from the hills, and the numbers of laborers carrying and transporting the stones, and finally the laborers supervising the stone-cutting and transportation laborers, which is clear through the following texts.

- Verses 15 and 16 in I Kings, Chapter 5, that reads as follows $^{27}$ : (15 Solomon also had 70,000 common laborers and 80,000 stonecutters in the hills, besides 3,300 officials who supervised the workers).

- Chronicles II, Chapter 2 (verses 1 and 2), the text reads as follows ${ }^{28}$ : (1 Solomon gave orders to build a temple for the Name of the LORD and a royal palace for himself. He conscripted seventy thousand men as carriers and eighty thousand as stonecutters in the hills and thirty-six hundred as foremen over them).

- Chronicles II, Chapter 2 (verses 17 and 18), the text reads as follows ${ }^{29}$ : (17 Solomon took a census of all the aliens who were in Israel, after the census his father David had taken; and they were found to be 153,600 . He assigned 70,000 of them to be carriers and 80,000 to be stonecutters in the hills, with 3,600 foremen over them to keep the people working).

- Through studying the preceding texts of the Old Testament, it becomes clear that the first text of Kings I, states the number of officials supervising the laborers as 3,300, while the other two texts in Chronicles II state that they were 3,600, which means a difference of 300 between the two stated numbers. So, which of the two is correct and which number should we take as true? Indeed, the manifest contradiction in the number of officials supervising the laborers who cut or transported stones is conclusive evidence of the flaw in the preceding texts of the Torah and impugns its credibility.

\section{Contradiction in the Measurements of the Alleged Temple}

Detailed measurements of the alleged temple are mentioned in some texts of the Old Testament, along with its height, width and length. This is clear through the following texts:

- Kings I, Chapter 6 (verses 1-3) include the following ${ }^{30}:(1$ In the four hundred and eightieth year after the Israelites had come out of Egypt, in the fourth year of Solomon's reign over Israel, 
in the month of Ziv, the second month, he began to build the temple of the LORD. 2 The temple that King Solomon built for the LORD was sixty cubits long, twenty wide and thirty high. The porch at the front of the main hall of the temple extended the width of the temple; that is twenty cubits, and projected ten cubits from the front of the temple).

- Chronicles II, Chapter 3 (verses 1-4) also includes the following ${ }^{31}$ : $(1$ Then Solomon began to build the house of the Lord at Jerusalem in Mount Moriah, where the Lord appeared unto David, his father, in the place that David had prepared in the threshingfloor of Ornan the Jebusite. 2 And he began to build in the second day of the second month, in the fourth year of his reign. 3 Now these are the things wherein Solomon was instructed for the building of the house of God. The length by cubits after the first measure was threescore cubits, and the breadth twenty cubits. And the porch that was in the front of the house, the length of it was according to the breadth of the house, twenty cubits, and the height was an hundred and twenty: and he overlaid it within with pure gold).

Reviewing the first text quoted from Kings I, we find that it identifies the length of the house (temple) as 60 cubits and its width as 20 cubits and also states its thickness; that is the height of the temple, as 30 cubits. It also illustrates that the temple is preceded by a 20 -cubit long porch, being equal to the width of the temple, while its width is 10 cubits. However, the height of the porch is not identified in this text.

As for the second text quoted from Chronicles II, it determines the length of the temple as 60 cubits and its width as 20 cubits, just as it was is mentioned in the first text, without mentioning the height. It also indicates that measurement of the porch that precedes the temple, stating that its length is 20 cubits, without referring to its width. Yet, it determined the height of the porch as 120 cubits.

Comparing the above two texts, it becomes clear that the measurements of the temple and the porch preceding it are as follows:

1. The length of the house (temple) is 60 cubits, its width is 20 cubits and its height is 30 cubits.

2. The length of the entrance porch preceding the temple is 20 cubits, being equal to the width of the temple, its width is 10 cubits and its height is 120 cubits. What is interesting here is that the height of the temple is 30 cubits (about15 m), and that the height of the porch preceding it is 120 cubits (about $60 \mathrm{~m}$ ), which constitutes a clear architectural and geometric contradiction, since the porch - which is considered the entrance to the temple - cannot be four times as high as the temple itself, fig. 9.

This conflicts with all conventional designs in all monumental and historical buildings. This manifest and unjustified contradiction between the height of the temple's entrance (120 cubits) and the height of the temple itself ( 30 cubits) led a Western (Jewish) researcher, Tony Badillo, to admit it, when he said $^{32}$ : "Drawing shows what Solomon's temple would look like with a height of 30 cubits (Kings I 6:2) and a Porch of 120 (Chronicles II, 3:4), not very visually appealing. No ancient or modern architect would want to claim such a miscreation; the porch is four times the height of the building!"

He openly admitted that according to the description in the Old Testament, since the temple's entrance is four times as high as the temple itself; the ratios are entirely unattractive from the visual perspective.

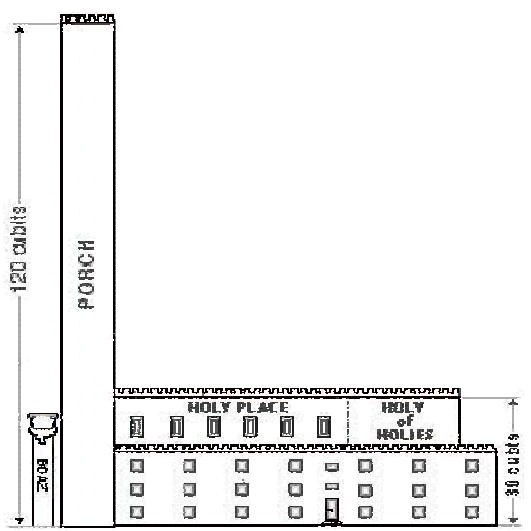

Figure 9a. An Imagined Drawing According to the Description Mentioned in the Old Testament, which Indicates the Degree of Contradiction in the Temple's Height in Relation to the Height of the Building of the Temple Itself (According to the Drawing of Tony Badillo ${ }^{33}$ ).

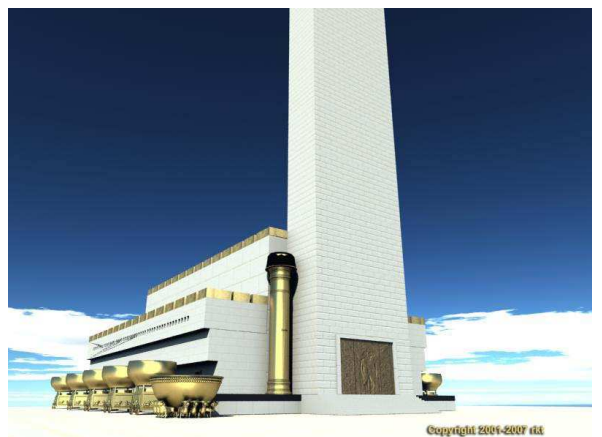

Figure 9b. Imagined Drawings According to the Virtual Heights of the Entrance as Described in the Old Testament, which Illustrate the Lack of Proportionality in the Height of the Temple's Entrance in Relation to the Building of the Temple Itself. 


\section{Contradiction in the Height of the Two Pillars in Front of the Temple's Porch}

According to what is mentioned in some texts of the Old Testament, two brass pillars are placed in front of the Temple's porch; one of which is called Jachin, while the other is called Boaz. This is clear through the following texts:

The following is stated in Kings I, Chapter 7, verses 15- $21^{34}$ : (15 Thus, he fashioned the two pillars of brass, of eighteen cubits high each; and a line of twelve cubits did compass it about; [and so] the other pillar. 16 And he made two capitals of molten brass, to set upon the tops of the pillars; the height of the one capital was five cubits, and the height of the other capital was five cubits. 21 And he set up the pillars at the porch of the temple; and he set up the right pillar, and called the name thereof Jachin; and he set up the left pillar, and called the name thereof Boaz).

- It is also mentioned in Kings II, Chapter 25 (verses 8 -17) that $^{35}$ : (8 nineteenth year of King Nebuchadnezzar king of Babylon, came Nebuzaradan, captain of the guard, a servant of the king of Babylon, unto Jerusalem: 9 And he burnt the house of the Lord, and the king's house, and all the houses of Jerusalem, and every great man's house burnt he with fire. 16 The two pillars, one sea, and the bases which Solomon had made for the house of the Lord; the brass of all these vessels was without weight. 17 The height of the one pillar was eighteen cubits, and the chapiter upon it was brass: and the height of the chapiter was three cubits; and the wreathen work, and pomegranates upon the chapiter round about, all of brass: and like unto these had the second pillar with wreathen work).

- Besides, Chronicles II, Chapter 3 (verses 15 -17) includes the following ${ }^{36}$ : (15 Also he made before the house two pillars of thirty and five cubits high, and the capital that was on the top of each of them was five cubits. 16 And he made chains in the Sanctuary, and put them on the tops of the pillars; and he made a hundred pomegranates, and put them on the chains. 17 And he set up the pillars before the temple, one on the right hand, and the other on the left; and called the name of that on the right hand Jachin, and the name of that on the left Boaz).

It is clear through the two quotes from Kings I and II that the length of each pillar is 18 cubits, yet the quote from Kings I indicates that the height of the capital is 5 cubits. However, the quote from Kings II indicates that the height of the capital is 3 cubits. So, which version should we acknowledge? As regards the third quote from Chronicles II, it is clear that the length of the pillar is 35 cubits and that it carries a capital that is 5 cubits high, figure 10 .

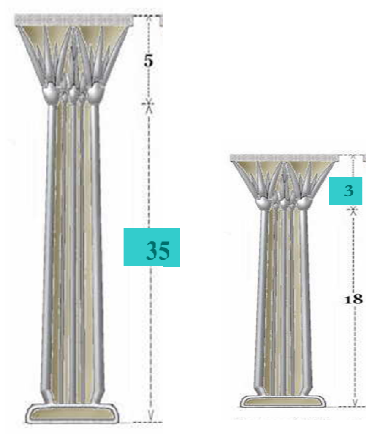

Figure 10. Is the Height of the Pillar 18 Cubits as Mentioned in Kings I, or 35 Cubits as Mentioned in Chronicles II? Is the Height of the Capital 5 or 3 Cubits?

Reviewing the preceding three texts, the glaring contradiction regarding the height of these two pillars becomes manifest; is the height of the pillar 18 cubits - as is mentioned in Kings I and II - or 35 cubits as is stated in Chronicles II? Is the height of the capital 5 cubits - as is mentioned in Kings I and Chronicles II - or 3 cubits as is mentioned in Kings II?

\section{The Contradiction in the Capacity and Measurements of the Round Sea:}

Among the elements mentioned in the description of the alleged temple is a round bronze basin that was placed in front of the temple and that was filled with water, where the priests of the temple would bathe (See fig. 14). The descriptions, measurements and capacity of this basin or sea were mentioned in the following two texts:

- Kings I, Chapter 7 (verses 23, 26), includes the following ${ }^{37}$ : (23 And he made the molten sea of ten cubits from brim to brim, round in compass, and the height thereof was five cubits; and a line of thirty cubits did compass it round. 26 And it was a hand-breadth thick; and the brim thereof was wrought like the brim of a cup, like the flower of a lily; it held two thousand baths).

- The following is also mentioned in Chronicles II, Chapter 4 (verses 2, 3) (38: $^{38}$ Also he made the molten sea of ten cubits from brim to brim, round in compass, and the height thereof was five cubits; and a line of thirty cubits did compass it round about. 3 And it was a handbreadth thick; and the brim thereof was wrought like the brim of a cup, like the flower of a lily: it received and held three thousand baths). Reviewing the preceding two texts, two discrepancies become clear, and they are as follows:

1. It is stated in Kings I and Chronicles II that the sea is round and that it is 10 cubits wide brim to brim, and its circumference is 30 cubits! Indeed, a well-known mathematical law links circumference and radius (circumference $=$ 
2 - $\pi$ - radius), which means that if the diameter of the sea is 10 cubits, then its circumference must be 31.4 cubits, and not 30 cubits as is mentioned in the texts of the Torah, which in turn indicates the alteration of these texts.

2. It is mentioned in the first text that this round sea holds two thousand baths, while it is stated in the second text that the sea receives and holds three thousand baths, which constitutes an unmistakable contradiction. So, which text should we believe?

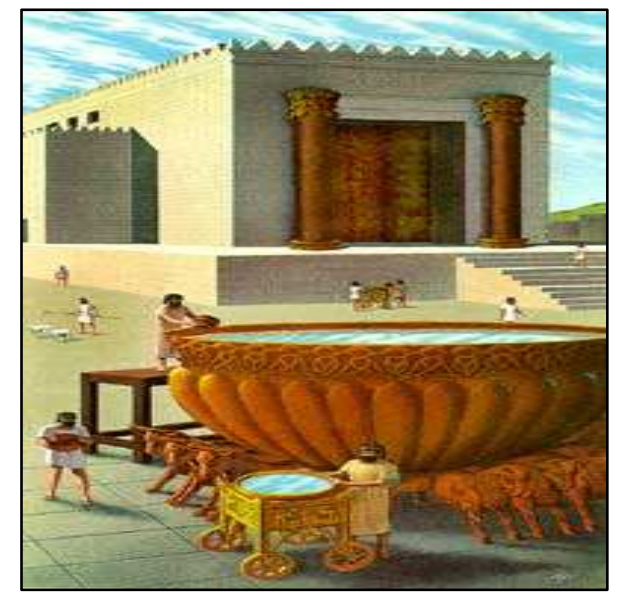

Figure 11. An Imagined Drawing of the Round Sea, which was Placed in Front of the Temple

5. The Contradiction Regarding the Weight of Gold Sent to Solomon

It is mentioned in several texts of the Old Testament that gold was used to overlay the walls, doors and some components of the temple. The following two texts indicate that King "Huram", whom Solomon employed in building the alleged temple, had sent gold with his slaves and Solomon's slaves from Ophir city. Thus, it is clear through comparing the two texts that there is a contradiction regarding the weight of the sent gold:

a. Kings I, Chapter 9 (verse 28), includes the following ${ }^{39}$ : (28 And they came to Ophir, and fetched from thence gold, four hundred and twenty talents, and brought it to king Solomon).

b. On the other hand, Chronicles II, Chapter 8, verse 18 - includes the following ${ }^{40}$ : (18 And Huram sent him by the hands of his servants ships, and servants that had knowledge of the sea; and they came with the servants of Solomon to Ophir, and fetched from thence four hundred and fifty talents of gold, and brought them to king Solomon).
So, which of these two texts is correct, and which one should we believe? In the following text, in Kings I, it is stated that the weight of gold is 420 talents, while the second text, in Chronicle II, mentions that its weight is 450 talents.

6. The Stones of Western Wall (Al-Buraq Wall) Prove that It is not Part of the Alleged Temple

One of the most important Islamic monuments associated with the Al-Masjid Al-Aqsa is Al-Buraq (White, long animal, larger than a donkey and smaller than a mule) Wall, which constitutes the south-western part of Al-Masjid Al-Aqsa's wall; its length is $48 \mathrm{~m}$ while its height is about $17 \mathrm{~m}$. It is considered part of the Islamic properties, since it constitutes a part of Al-Masjid Al-Aqsa, and it has a firm relation with $\mathrm{Al}-\mathrm{Isra}$ ' and $\mathrm{Al}-\mathrm{Mi}$ 'raj Journey. Muslim historians believe that the Prophet (peace be upon him) tied Al-Buraq to $i t^{41}$.

And though the Jews do not have any legal right to this wall, the tolerant Muslims have allowed them to visit it and cry in front of it. Hence, they called falsely and mendaciously call it the Wailing Wall. Likewise, the wall was not a place of worship for the Jews until the sixth century A.C., as is mentioned in "The Jewish Encyclopedia"42.

Accordingly, the Jews themselves admit that they started to use Al-Buraq Wall or the Western Wall as a place of worship since the sixteenth century only. However, they frequently attempted to usurp it since the British Mandate of Palestine and until the Al-Buraq Revolution on August 23, 1929 A.C., in which tens of Arabs and Jews were killed and which resulted in the formation of an international commission to determine the rights of the Arabs and the Jews concerning Al-Buraq Wall. The committee was headed by a former Swedish minister of foreign affairs and included two Swiss members and a Dutch. After conducting an inquiry, the commission released a report in 1930 in which it upheld the unquestionable right of Muslims to the property of Al-Buraq Wall. The report states: "To Muslims alone belongs the property of the Western Wall, and they alone have the title thereto as it forms an integral part of the esplanade of Al-Aqsa Mosque that is a waqf property. To Muslims too belongs the property of the pavement located in front of the Wall and in front of the district known as the Maghrebi quarter, as it is a waqf property in accordance with the provisions of Islamic law"43.

However, in 1967, the Israeli authorities usurped Al-Buraq Wall and laid their hand on the AlMaghariba Gate (Moroccans Gate; one of the gates of Al-Masjid Al-Aqsa). Such is the historical proof that maintains the right of the Muslims to Al-Buraq Wall. 
Added to this is a monumental proof, which ascertains the falsity of the Jewish claims about their having any right to the wall. This is because the Torah introduced a definite description of the stones used in building the alleged temple.

The following is mentioned in Kings I, Chapter 5:1744: "17 By the king's orders great stones, stones of high price, were cut out, so that the base of the house might be made of squared stone".

The following is also mentioned in Chronicles I, Chapter 22: $2^{45}:$ And David commanded to gather together the strangers that were in the land of Israel; and he set masons to hew wrought stones to build the house of God)."

So, the preceding two texts clearly state that the stones used in building all parts of the alleged temple were square shaped, while the stones used in building Al-Buraq Wall, as well as all other monumental buildings are rectangular in shape, figure 12 .

It is also well-known from geometric and architectural perspectives that square stones are not used in building all the foundations and walls of old or modern buildings, and that rather, rectangular stones are mainly used, knowing that this contradicts the geometric and architectural principles known to specialists.

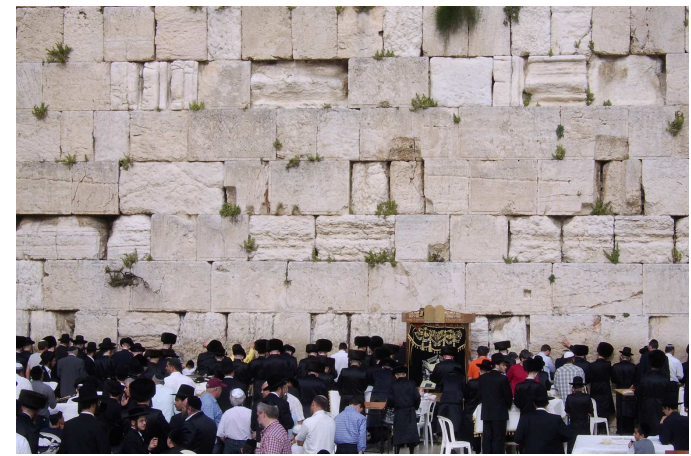

Figure 12. The Stones of Al-Buraq Wall are Rectangular and not Square as is Mentioned in the Old Testament, which is Proven through All Monumental Excavations at the Foundations of Al-Masjid Al-Aqsa.

This gives conclusive proof of the differences of the stones used in building Al-Masjid Al-Aqsa in general and Al-Buraq Wall in particular from that mentioned in the Old Testament. In addition, the Old Testament mentions that unwrought stones must be used in building the temple (house of God), (Kings I, 6: 7-10). This contradicts visual reality, for all the huge stones used in building the Western Wall of are hewn stones, which had been dressed by chisels and pickaxes. This contradicts what is mentioned in the Old Testament ${ }^{46}$.
7. The Total Area of the Buildings and Yard of the Temple is Larger than the Area of the Old City

An accurate and detailed description of the elements of the alleged temple is mentioned in Ezekiel chapter through a vision seen by Ezekiel (one of the prophets of the Jews), along with an indication that the God of the Children of Israel ordered him to tell his people about this vision. The vision begins with the words that Ezekiel saw a man with a measuring stick - six cubits and a span of the hand (10 1/2 feet) long - in his hand (Ezekiel 40:5). It reads as follows ${ }^{47}$ : ( 5 I saw a wall completely surrounding the temple area. The length of the measuring rod in the man's hand was six long cubits, and a handbreadth).

Then, the man started to describe to Ezekiel, in an accurate and detailed manner, the temple and the surrounding buildings and courts, providing him with measurements and using the measuring stick mentioned above. At the end of this description, he said to him that there was a square-shaped wall encompassing the temple along with the surrounding buildings and open courts and that the length of that wall is 500 reeds, which is clear through the following quote from Ezekiel (Chapter 42, verses 15 $19)^{48}:$ (15 Now when he had made an end of measuring the inner house, he brought me forth toward the gate whose prospect is toward the east, and measured it round about. 16 He measured the east side with the measuring reed, five hundred reeds, with the measuring reed round about. $17 \mathrm{He}$ measured the north side, five hundred reeds, with the measuring reed round about. 18 He measured the south side, five hundred reeds, with the measuring reed. $19 \mathrm{He}$ turned about to the west side, and measured five hundred reeds with the measuring reed. $20 \mathrm{He}$ measured it by the four sides: it had a wall round about, five hundred reeds long, and five hundred broad, to make a separation between the sanctuary and the profane place).

What is mentioned in Ezekiel illustrates that the total area of the sacred part containing the temple and the other buildings and yards equals the area encompassed by the external square wall, which is 500 reeds long from the four sides. Hence, if the length of the measuring stick (reed), according to what is mentioned, [i.e. about $3.20 \mathrm{~m}$, supposing that the reed (cubit) equals $50 \mathrm{~cm}$ and the span of the hand equals $20 \mathrm{~cm}$ ), then the area of the sacred part containing the building of the alleged temple and surrounding buildings and open courts within the wall, would be about $2.65 \mathrm{~km}^{2}$.

Thus, when we know that the area of the Old City within the walls is about $1 \mathrm{~km}^{2}$, fig. 13 , then this means that the total area of the sacred part of the temple and surrounding area is about two and a half times larger than the area of the Old City, which is 
completely illogical and which is belied by all archeological and historical maps.

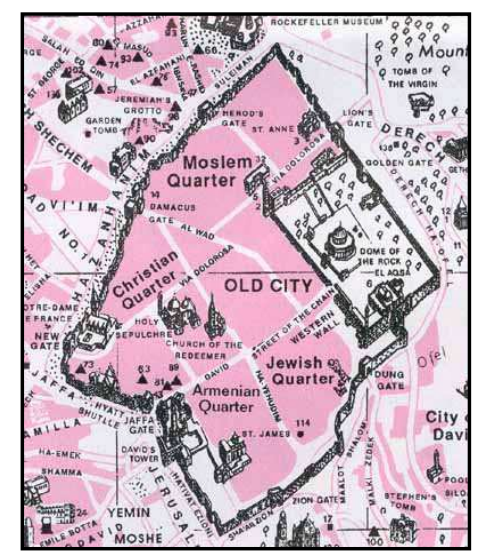

Figure 13. A Perspective Drawing of the Old City Within the Walls, which Shows Al-Masjid Al-Aqsa as Part of the City, while It is Determined in Ezekiel that the Area of the Alleged Temple is Two and a Half Times Larger than the Old City

\section{Conclusion}

Several significant findings have been reached through the present study, which will be elaborated in the following points:

1. The blessed Al-Masjid Al-Aqsa, which is mentioned in the Ever Glorious Qur'an (in Sura Al-Isra'), is the blessed spot that is now called Al-Haram Al-Qudsi and is surrounded by the great wall along with the buildings and monuments that have been built on it, on top of which is Al-Masjid Al-Qibli (covered Masjid) and the Dome of the Rock.

2. In the creed of the Muslims, Al-Masjid Al-Aqsa is the second Masjid ever built on earth, next to Al-Bayt Al-Haram (The Sacred House) in Makkah Al-Mukarramah. Therefore, the history of Al-Masjid Al-Aqsa, according to the Muslims, dates back to the distant past, unlike Jewish history in which Al Masjid emerges from the moment the temple was built, according to their own claim.

3. It has been proven through satellite searches that the orientation of the Qiblah of the legally defined Al-Masjid Al-Aqsa is towards Makkah Al-Mukarramah (the Qiblah of the Muslims). This orientation preceded the Islamic conquest of Jerusalem by hundreds of years, and it is proven through the foundations and bases of the wall of the Masjid that dates back to Herod the Great. This in turn exposes the falsity of the Jewish claims that the alleged Solomon's temple was oriented towards the west, which cannot be explained in a plausible manner.
4. Analytical studies have proven the extent of geometric identicalness between Al-Masjid AlAqsa and the Honorable Ka 'bah in its original measurements, as regards shape and ratios. Their geometric shape is identical, being a scalene, which is a rarely used shape in architectural designs. Besides, their ratios are almost the same, which agree with the "Golden Ratios". It comes on top of the geometric ratios that have been used in buildings since the distant past because it is the most comfortable ratio from the visual perspective.

5. It has been proven through studies of the texts of the Old Testament describing the alleged Solomon's temple that there are clear multiple contradictions in the geometric description and the measurements of that alleged building, whether the contradiction lies between the texts themselves or between it and geometric logic that is acknowledged by specialists and experts. The following are the most important contradictions:

a. Contradiction in the numbers of officials supervising the laborers.

b. Illogical geometric ratios of the alleged temple, especially the height of the porch that antecedes the temple. This led all Israeli architects and archeologists not to adhere to these measurements when drawing the graphic interfaces and sectors of the alleged temple or upon making miniature models of it.

c. Contradiction in the height of the two pillars anteceding the temple and in the height of the capital that tops them.

d. Contradiction in the relation between the diameter and the circumference of the round sea, and also in the quantity of water that it can take and receive.

e. Contradiction in the weight of the gold sent from Huram to Prophet Solomon to be used in the alleged temple.

f. The description in the Torah of the stones used in building the alleged temple as square and unhewn diametrically contradicts the hewn rectangular stones that were used in establishing the foundations of the legal AlMasjid Al-Aqsa and its walls and buildings; rather, the stones used in all monumental buildings in Jerusalem. This gives firm proof of the falsity of the allegation of the "Wailing Wall", which the Jews claim to be part of the remains of the third temple built by Herod the Great.

g. The area of the temple and the surrounding buildings and open yards, as is mentioned in 
Ezekiel, equals two and a half times the area of the Old City within the walls.

6. The preceding clear contradictions raise doubts about the existence of the alleged temple, which provide proof that Prophet Solomon renewed the building of Al-Masjid AlAqsa, and did not build a temple, as is mentioned in Islamic texts.

7. It is an aspect of the inimitability of the Glorious Qur'an that it mentions in Sura Al-Baqarah confirmation of the alteration and distortion in the texts of the Old Testament at a time in which the Old Testament had not yet been translated into Arabic, but was written in other languages (Hebrew, Chaldean and Greek). For, Allah (Glorified and Exalted be $\mathrm{He}$ ) says, "And there are among them (Jews) unlettered people, who know not the Book, but they trust upon false desires and they but guess. Then woe to those who write the Book with their own hands and then say,

[This is from Allah," to purchase with it a little price! Woe to them for what their hands have written and woe to them for that they earn thereby.] (Al-Baqarah: 79).

\section{Reference}

1 'A. Zayid. 2000. Al-Quds Al-Khalidah [Eternal Jerusalem]. Cairo: Egyptian's History series (197), General Egyptian Book Organization. pp. 13.

2 M. 'Abdul-Qadir. 2001. Watha'iq Al-Yahud AsSirriyyah Lil-Istila' 'ala Al-Masjid Al-Aqsa [Jewish Secret Documents to Usurp Al-Masjid Al-Aqsa]. Alexandria, Egypt: its author, pp. 11.

3 'A. Zayid, ibid, pp. 181.

4 Y. Wazeri. 2005. At-Tatawwur Al- 'Umrani watTurath Al-Mi 'mari li-Madinat Al-Quds AshSharif [Constructional Development and Architectural Heritage of the Noble Jerusalem]. Cairo: Ad-Dar Ath-Thaqafiyyah for publication. pp. 127.

5 Dr. Hassan Zhazha mentioned that the area of Al-Masjid Al-Aqsa is rectangular in shape being oriented from north to south towards the Qiblah in Makkah Al-Mukarramah, but he did not support this claim with proof. See $\mathrm{H}$. Zhazha. 1973. Israel Rakizat Al-Isti 'mar waal'idwan Baina AL-Muslimin [Israel; the Cornerstone of Colonialism and Enmity among the Muslims]. Cairo: Islamic Research Magazine. pp. 116- 117.

6 http:// www.qiblalacator.com (Accessed February 9, 2012).

7 'A. Zayid, ibid, pp. 125.
8 W. F. Albright. 1971. Athar Filistin [Monuments of Palestine]. Arab Republic of Egypt: Supreme Council for Islamic Affairs. pp. 31.

9 F. K. Tashkandi. 1999. 'Ash-Shawahid min AshShari 'ah wal- 'Imarah fi Ihtida' Al-Muslimin ila Al-Qiblah Al-Ula'. Architecture of the mosque Symposium ( $7^{\text {th }}$ vol.). Kingdom of Saudi Arabia: College of Architecture and Planning, King Saud University. pp. 73-121.

10 http://www.ritmeyer.com/2011/03/08/ mughrabi-gate-bridge-is-back-on-theagenda/ (Accessed June 10, 2012).

11 'A. Al-`Arif. 1999. Tarikh Al-Quds [History of Jerusalem] $3^{\text {rd }}$ ed. Cairo: Dar Al- Ma'arif. pp. 303.

12 A. Zaki and M. S. Al-Junaydi. 1943. Al-Mabadi' Al-Handasiyyah [Geometric Principles]. Cairo: Ministry of Al-Ma 'arif Al- 'Umumiyyah. pp. 107.

13 'I. El-Said \& A. Parman. 1976. Geometric Concepts in Islamic Art. London: World of Islamic Festival Publishing Company Ltd. pp.82.

14 M. Talu. 1982. Al-Funun Az-Zukhrufiyyah [Decorative Arts]. Damascus: Dar Dimashq litTiba `ah wan-Nashr [Damascus House for Printing and Publishing. pp. 29.

15 Y. Wazeri. 2007. Al-Ka'bah Al-Musharrafah; Dirasah Tahliliyyah Lil-Khasa'is At-Tasmimiyyah [The Honorable Ka'bah; an analytical study of the characteristics of the design. Cairo: Inter Build Conference Research Register 14

16 K. Creswell. 1984. Early Muslim Architecture. $1^{\text {st }}$ ed. Damascus: Dar Qutaybah. pp.13.

17 A. Al-Azraqi. 1985. Akhbar Makkah wa ma Ja'a fiha min Al-Athar [News of Makkah] ( $2^{\text {nd }}$ ed.). Beirut: Rushdi Salih Mulhin. pp.64.

18 The current measurements of the Ka 'bah are as follows: The north-east side: $11.68 \mathrm{~m}$, the north-west side: $9 \mathrm{~m}$, the south-west side: $12.04 \mathrm{~m}$, and the south-east side: $10.18 \mathrm{~m}$. See: Y. 'A. 'Abdur-Rahim. 1998. "Al-Qissah AlKamila Li-Bina' Bayt Allah Al-Haram [The complete story for building the Sacred mosque]". 'Ammar Magazin, issue no.19, Kuwait, pp.23- 60.

19 A. R. Muhammad. 2000. Al-Masjid Al-Haram biMakkah Al-Mukarramah [The sacred mosque in Honorable Makkah] . $2^{\text {nd }}$ ed. Cairo: Ad-Dar AlMisriyyah Al-Lubnaniyyah. pp. 24.

20 Some people drew my attention to the point that Dr. Haytham ar-Ratrut pointed out that there is a parallel between the angles of the Honorable Ka'bah and those of Al-Masjid Al-Aqsa. So, after referring to his study, I noticed that he did not assume any comparison between the real shape of the Honorable Ka 'bah and Al-Masjid Al-Aqsa in maintaining this proposition. Rather, he drew on the inverse 
shape, making the Yemini Corner in the place of the Black Stone Corner, without indicating the reason for that. However, it is well-known that geometric comparisons should apply to real and actual shapes of buildings. See:nH. Ar-Ratrut. 2005. "Al-Masjid Al-Aqsa fil-Athar AlQur'aniyyah" [The Farthest mosque in the Qur'anic Archeology]. Journal of Bayt Al-Maqdis (Islamic Jerusalem Studies). United Kingdom. no.1. pp.1-32.

21 According to the Jews, David (Dawud) and Solomon (Sulayman) are kings and not prophets, while in our Muslim creed, they are two prophets sent by Allah (Exalted be He).

22 See for instance: R. Najm .2004. Al-Madkhal Lil-Madinah Al-Muqaddasa [Entry into the Sacred City]. Amman: The General International Islamic Conference of Jerusalem, pp. 83.

23 For more information on Qur'anic verses and authentic prophetic Hadiths that confirm this fact, the reader can refer to: 'I. Al-Qaddumi. 2008. Al-Masjid Al-Aqsa, Al-Haqiqah wat-Tarikh [The Farthest mosque, Fact and History]. $2^{\text {nd }}$ ed. Hawli, Kuwait: Jerusalem Center for Documentary Studies. pp. 10 \& 14.

24 Many studies have touched on the contradictions and distortion in the Bible. See, for instance: N. 'A. As-Samirra'i. 2003. At-Tawrah bayna Fuqdan Al-Asl wa Tanaqud An-Nass The Torah between loss of the Original and Contradictions of the Text], $2^{\text {nd }}$ ed. London: Dar Al-Hikmah. Other researches also elaborated on refuting claims of the presence of the alleged temple in general. See: S. H. Ar-Riqib. 2002. "Naqd Al-Maza 'im AsSuhyuniyyah fi Haykal Sulayman [Refuting the Zionist Allegations on Solomon's Temple]". Islamic University Magazine. Vol. $10,1^{\text {st }}$ issue, Gaza: Faculty of Usul Ad-Din, pp. 41 - 91.

25 'A. Al-Misiri. 1999. Mawsu'at Al-Yahud wa AlYahudiyyah wa As-Suhyuniyyah. Vol. 4. Cairo: Dar Al-Shuruq.

26 See also the description of the alleged temple in: http://www.templeinstitute.org (Accessed May 11, 2012).

27 See New International Version of the Bible in: http:// www.biblegateway.com (Accessed May 3, 2012).

28 ibid

29 ibid

30 ibid

31 ibid

32

www.kingsolomonsastonishingtemplesecrets.or g.Accessed May 5, 2012).

33 ibid

34 The English-Hebrew version of the Bible in: http:// www.mechon:nmare.org (Accessed May 3, 2012).

35 King James version of the Bible, Ibid.

36 ibid

37 The English-Hebrew version of the Bible in: http:// www.mechon:nmare.org (Accessed May 11, 2012).

38 ibid

39 ibid

40 ibid

41 'A. Mustafa. 2006. Qadiyyat Al-Quds (The Jerusalem Issue). Cairo: the Supreme Council for Islamic Affairs, Egyptian Ministry of Endowments. pp.49.

42 For more details, see: J. Al- 'Ayyash. 2007. Ha'it Al-Buraq [Al-Buraq Wall]. Cyprus: Jerusalem Center for Documentary Studies.

43 M. M. Iskandar. 1972. Al-Quds wa Bayt Lahm [Jerusalem and Bethlehem] (New and enlarged edition). Cairo: Maktabat Al-Mahabbah. pp. 70.

44 -. 1970. The Holy Book. Cairo: The Holy Book House,

45 The English-Hebrew version of the Bible, Ibid.

46 For more details, see: B. Al- 'Abid. 2001. "AlHuwiyyah Al-Mi`mariyyah wa Atharuha fi Tahdid Al-Huwiyyah As-Siyasiyyah li Madinat AlQuds [Architectural Identity and its Impact in Shaping the Political Identity of Jerusalem]". Journal of the Association of Arab Universities for Studies and Research Engineering. Iraq: College of Engineering, Bagdad Univ. pp. 1-70. http://www.palestineinfo.com/arabic/alquds/mukhtarat/dr_alabed/ f7.htm (Accessed May 14, 2012).

47 New International Version of the Bible, ibid.

48 Kings James, English version, ibid 